\title{
Research Paper Relationship between the farm harvest price index and general price index of Amravati division
}

See end of the paper for authors' affiliations

\section{Correspondence to :}

\section{K.D. CHOPDE}

Department of Agricultural Economics and Statistics, Post Graduate Institute, Dr. Panjabrao Deshmukh Krishi Vidyapeeth, AKOLA (M.S.) INDIA

Email:

kavita_srg@rediffmail.com

Paper History :

Received : 07.01.2015;

Revised : 19.01.2015

Accepted : 05.02.2015
ABSTRACT : Agricultural price policy plays an important role in achieving growth and equity in the Indian economy in general, and the agriculture sector in particular. The major underlying objective of the Government's price policy is to protect both producers and consumers. Agricultural price policy is basically aimed at intervention in the agricultural produce markets with a view to influencing the level of fluctuations in prices and price-spread from farm-gate to the retail level achieving food security at both the national and household levels is one of the major challenges in India today. The objectives of study were, to study the behaviour of farm harvest price and general price, to workout the price indices of farm harvest price and general price, to study the relationship between the farm harvest price index and general price index and to study the relationship between the deflation of farm harvest price index and general price index. The present study was based on secondary data. General price data was collected from the various issues of socio-economic review of district publications of Akola, Amravati, Buldhana, Yavatmal. Farm harvest price was collected from Directorate of Economics and Statistics, Ministry of Agriculture, Government of India on a continuous basis. The period of study and secondary data from 2000-01 to 2010-11 was collected for analysis point of view. Price index, correlation co-efficient were calculated to show the diverse relationship between the prices. The study concludes that, behaviour of farm harvest prices and general prices were slightly pices were fluctuates, from year 2000-01 to 2010-11. The prices of all selected crops were highly fluctuates and increases after the 2008-09 to 2010-11 as campier to year 2000-01. In Buldhana, Akola, Amravati and Yavatmal district. FHPI and GPI were highly increases from the year 2008-09 to 2010-11. In case of gram, tur and soybean crops in Amravati, Akola and Yavatmal districts. Relationship between FHP Indices and GP Indices were significant in wheat, jowar, maize, gram, tur, cotton and soybean crops in all district. Correlation between deflation of FHPI and GPI in most of crops in four districts were non significant, the FHP and general price level were increases from the year 2001 to 2010-11.

KEY WORDS : Harvest price, Index, General price index

HOW TO CITE THIS PAPER : Chopde, K.D., Kadam, M.M. and Bondhare, V.O. (2015). Relationship between the farm harvest price index and general price index of Amravati division. Internat. Res. J. Agric. Eco. \& Stat., 6 (1) : 106-112. 